\title{
Russian-U.S. Relations: Torn between the Practical and Ideational Agendas
}

\section{Desperate Clash of Perceptions}

Ivan V. Safranchuk

\section{Abstract}

The article aims to develop an analytical model for foreign policy experts in order to gain a better understanding of Russian-U.S. relations. The content of Russian-U.S. relations is categorized into practical and ideational agendas. This article argues that the dynamics of interaction between these two coexisting agendas is crucial for understanding the dynamics of Russian-U.S. relations. Descriptive analysis is used to study, categorize, and explain such dynamics. The paper also includes an analysis of the correlation between the practical and ideational agendas. The proposed approach helps to better understand

Ivan V. Safranchuk

Senior Fellow, Institute of International Research, MGIMO University;

Associate professor, National Research University-Higher School of Economics.

SPIN RSCI: 9754-1094

ORCID: 0000-0003-2214-6628

ResearcherID: 0-3257-2017

Scopus AuthorID: 57193867458

e-mail: latuk.info@gmail.com

Institute of International Research, MGIMO University

Office 319, 76 Vernadsky Prospect, Moscow, Russia

National Research University-Higher School of Economics

20 Myasnitskaya Str., Moscow, Russia

This article is an output of a research project "New approaches towards the analysis of RussianUS relations in XXI century", implemented as part of the Individual Research Program of the School of World economy and International Affairs at National Research University - Higher School of Economics. 
how the unique conceptual landscape of Russian-U.S. relations influences their practical domain. This approach can be used as a separate explanatory model or in combination with explanatory models of major theories.

Keywords: Russian-U.S. relations, practical agenda of Russian-U.S. relations, ideational agenda of Russian-U.S. relations, world order

fter the end of the Cold War, Russia and the U.S. sought to
make fundamental changes in their relationship. On both
sides the ambition stretched much farther than merely reducing disagreements and tensions. The two countries were willing to make a major shift to regarding each other as belonging to a common group of nations. The day after the Belavezha Accords were signed in December 1991, James Baker, then U.S. Secretary of State, said: "If during the Cold War we faced each other as two scorpions in a bottle, now the Western nations and the former Soviet republics stand as awkward climbers on a steep mountain. Held together by a common rope, a fall toward fascism or anarchy in the former Soviet Union will pull the West down, too. Yet equally important is that a strong and steady pull by the West now can help them to gain their footing so that they too can climb above to enduring democracy and freedom. Surely, we must strengthen that rope, and not sever it" (Baker, 1991).

Russia's then Foreign Minister Andrei Kozyrev read this as a contrario to the Fulton speech. A few months earlier he had encouraged Baker to declare: "Russia and the West are not divided anymore, they are together" (Aven and Kokh, 2013). Boris Yeltsin accepted that thinking. In February 1992, he met George H. W. Bush at Camp David to discuss new Russian-U.S. relations and sign a declaration that stipulated the main principles for these relations. The first principle read: "Russia and the United States do not regard each other as potential adversaries. From now on, the relationship will be characterized by friendship and partnership founded on mutual trust and respect and a common commitment to democracy and economic 
freedom" (Declaration, 1992). Other principles promised to dismantle the remnants of the Cold War, open venues for broad civil society contacts, and make joint efforts against new international challenges. The declaration concluded: "In adopting these principles, the United States and Russia have launched a new era in our relationship. In this new era, we seek a peace, an enduring peace that rests on lasting common values. This can be an era of peace and friendship that offers hope not only to our peoples but to the peoples of the world" (Declaration, 1992).

Today, a quarter of a century after the Declaration, bilateral relations between the two countries are at a very low level. In fact, they are probably worse than even during the Cold War. This trajectory in the development of Russian-U.S. relations is explained differently.

In the U.S., the mainstream debate has evolved between liberals and structural realists, in particular, offensive neorealists. Structural realism argues that a state's behavior is largely shaped by the structure of the international political system. Operating in an anarchic international system, which is a reality today, states rely on the principle of self-sufficiency and seek to ensure their survival (Waltz, 1979: 105). This means that "balances of power recurrently form, and states tend to emulate the successful policies of others" (Waltz, 1979: 124).

Offensive neorealists claim that "great powers recognize that the best way to ensure their security is to achieve hegemony now, thus eliminating any possibility of a challenge by another great power" (Mearsheimer, 2001: 35). From this perspective, Russia is inclined to seek hegemony at its borders and to assertively resist others' influence in this zone. John J. Mearsheimer thinks that the West came too close to Russia's borders, posing a real threat to it, which was easy to predict from the very beginning of NATO enlargement (Mearsheimer, 2014).

The prevailing liberal perspective is that Russia's foreign policy is mainly determined by the internal nature of its regime rather than by external conditions. Michael McFaul sees a difference in the foreign policy of Putin and Medvedev. He believes that after oppositional protests Putin used the U.S. in his reelection campaign as an enemy 
to legitimize his return to the Kremlin for a third term (McFaul, Sestanovich, and Mearsheimer, 2014).

It is not surprising that these two positions represent the mainstream debate in the West. They offered two strategies towards Russia right after the end of the Cold War, namely regime transformation and power balancing (Goldgeier and McFaul, 2003: 5). Since then U.S. policy has actually developed along a line lying in between these two different positions and never to the full satisfaction of any of the camps (although liberals have had more influence on U.S. practical policy).

Both strategies-regime transformation and power balancingdid not welcome Russia as it was. As Thomas Graham and Matthew Rojansky argue, "the most common U.S. policy responses to Russiafrom both Republican and Democratic administrations across three decades-have depended either on the hope that Moscow can be fully defeated or that it can become a friend and fellow democracy" (Graham and Rojansky, 2016).

Outside of the main liberal vs. realist debate on Russia, some think that Putin's mindset was shaped by his Soviet experience of service in the KGB. From his very first days in power Putin cherished a grand strategy of restoring Russia's geographical integrity and repute of the Russian state, which only gradually became evident to the outside world (Starr and Cornell, 2014).

In Russia, the debate focuses on what the U.S. and the West on the whole did wrong and how Russia was forced to react under pressure of necessity rather than willingly. This very much resembles what Mearsheimer wrote, making himself quite popular among Russian scholars. Yet the mainstream view in Russia best fits with defensive neorealism, in which Russia sees itself as a status-quo power. The view that Russian foreign policy is determined by its internal politics has been mostly marginalized within the Russian professional community in the last twenty years. This idea is present mostly in the discourse of the non-parliamentary opposition, nationalistic or extreme leftist groups who claim that Russian foreign policy is anti-national. The liberal group shares the Western liberal thesis that the Russian 
authorities have shifted to anti-Western sentiments because of its nondemocratic, under-reformed nature.

Russian mainstream scholars do not pay much attention to the internal grounds of Russian foreign policy, believing that internal affairs affect only the tactics of its implementation. While Russian specialists intensively, and with high quality, write on specific issues of Russian-American relations (such as arms control and missile defense), a broader analysis and generalizations of these relations are not common (and are often presented in essays rather than scholarly writings).

Such generalizations are made either within the discourse over the development of Russian foreign policy or within the discourse over the global order. The concept of "real sovereignty" introduced by Andrei Kokoshin (Kokoshin, 2006) influenced much of Russian thinking, although that influence, more indirect than direct, has been largely underestimated. As a result, in the second half of the 2000s, Russian scholars viewed Russia as relying increasingly on itself and looking for less engagement with the U.S. (Safranchuk, 2008), up to defining it as a "lonely power" (Trenin, 2009; Shevtsova, 2010). Increasingly on its own, Russia relied less on relations with the U.S. to achieve its foreign policy goals.

Within the Russian debate on the world order, which is also indirectly connected to the "real sovereignty" concept, the central question has been whether the world order with Western dominance exists and can be improved with Russia's input to serve Russian interests (Kortunov, 2016) or whether it is not existent anymore (Fenenko, 2017). The first option implies that Russia and the U.S. need to cooperate as two powers with special responsibilities in the world, while the second one suggests that Russian-American relations should solely be based on national interests. After 2014 an important part of the debate is how to manage the growing confrontation. Some stand for Russia's detachment as a way to avoid further worsening of relations with the West (Miller and Lukyanov, 2016), others see Russia's self-reliance as inevitable for its future development (Nikonov, 2015), and still others, as a good chance for it in a new Cold War (Karaganov, 2018). 
Notably, the prevailing views in Russia and the U.S. about each other are not new. The essentials of the two dominating explanatory narratives emerged back in the 1990s. One, as a combination of liberal and idealistic perspectives, claims that Russia did not change quickly and deeply enough to be able to sincerely share the views prevailing in the West and, thus, it cannot be fully accepted as a non-contradictory part of the West. The other maintains, from a realistic perspective, that the West tried to misuse Russia's weakness to get unilateral concessions on practical issues, which ultimately provoked Russia's resistance. These two approaches have matured in the writings of talented scholars, with the former one being mostly popular in the West, and the latter one, in Russia.

Importantly, the self-identification of Russian and U.S. scholars with their own country does not match how they perceive the other country. The mainstream school of thought in Russia sees it as a status-quo power, very much in line with defensive neorealism. In the U.S., different scholars may view Russia differently, but hardly as a proponent of the status-quo. In turn, Russia does not view the U.S. in the same way as mainstream American experts see their own country. This distortion of mutual perception makes Russian and American experts spend much time and effort arguing over who they actually are. Each side believes that it knows better what the other side is (because it is not what it declares). This approach locks Russia and the U.S. in a descending spiral of mutual distrust.

Russian-U.S. relations can be explained not only from each other's perspectives, but also within different theoretical approaches. As mentioned above, while offensive neorealism presents Russia as a normal hegemon, defensive realism makes it possible to present it in two different ways (depending on how one interprets facts), either positively as a status-quo power or in the negative as a revanchist nation going beyond a reasonable balance of power. From the liberal or neo-liberal perspective, Russia may be seen as too selfish and not cooperative enough. However, such arguments can also be mirrored with reference to American unilateralism and the U.S.'s occasional disregard of the UN. 
From a more traditional idealistic approach Russia may be presented as a state driven by the wrong ideas (from the dominant Western perspective). Yet the U.S. may also be presented in this way (from the dominant Russian perspective). Within the hegemonic stability theory, the U.S. can be presented as the hegemonic power maintaining international order and Russia as the challenger. One may also refer to Paul Kennedy's thesis about "imperialistic overstretch" complicating the hegemonic mission and helping the challenger. The World-System theory makes it possible to describe Russian-U.S. relations as a struggle between a leading core nation and a semi-peripheral nation.

The important methodological problem is that explaining RussianU.S. relations from any theoretical approach does not help much. Firstly, some of the theories provide, as mentioned above, mirror interpretations of Russia's and the U.S.s roles, depending on how one interprets facts. Secondly, in applying a theory to Russia-U.S. relations one gets just an interpretation of the fundamental processes and the underlying reasons for a change in these relations from the perspective of that theory. In a way, such application is relevant only to a particular theory (as an exercise to verify how universal its explanatory model is), but not to the essence of Russia-U.S. relations (or any other issue of the same nature) because the relevance of identified fundamental processes and the causes of change remains unverified. Quantitative and formal methods can hardly provide a comprehensive explanation, although they can contribute to finding statistical correlations relevant and important for further analysis. Traditional descriptive analysis is still an appropriate, if not indispensable, methodology to study Russia-U.S. relations. In this article descriptive analysis is aimed at studying, categorizing, and explaining under-researched elements of the phenomena.

Admitting the general observation that the agenda of RussiaU.S. relations involves not only pragmatic but also conceptual issues, this article assumes the existence of a fundamental polarity in U.S.Russian relations. One extreme is practical or concrete: it embraces specific and actual interest-based steps and actions that are pragmatic by nature. The other extreme can be defined as abstract or ideational, where ideas, values, concepts, and notions are formed; a final high- 
level vision of either country is formed in this abstract realm which manifests itself in actions. These two extremes underpin the distinctive tracks in Russian-U.S. relations.

Arms control and other hard-security issues, regional questions that are vital for security or economic interests of the countries, building of alliances and coalitions-all of these issues involve the practical national interests of Russia and the U.S. and constitute the practical agenda. Disputes over the principles of international behavior, interpretations of international law, questions of the world order and rules constitute the ideational agenda where visions rather than practical interests of Russia and the U.S. are important.

The central thesis of this article is that the study of the interaction of the two agendas is important for understanding the dynamics of Russian-U.S. relations. The first section of the article analyzes the dissonance between practical and ideational agendas in Russian-U.S. relations over the last twenty-five years. It shows that they coexist rather independently, in parallel to each other. This raises the question of how these agendas correlate, which constitutes the subject of the second section. The third section demonstrates how practical and ideational agendas have been developing and expanding over the past twenty-five years. The fourth section synthesizes the findings of the three stages of analysis and explains the current crisis in Russian-U.S. relations.

\section{PRACTICAL AND IDEATIONAL AGENDAS IN RUSSIAN-U.S. RELATIONS}

With the collapse of the Soviet Union, the U.S. and Russian leadership experienced an unprecedented commonality of views on both practical and ideational issues, which paved the way for a period of good relationship. However, it did not take long for Russian and U.S. views to start diverging on issues of practical interests (NATO expansion, missile defenses, Chechen separatism), as well as on the ideational agenda (different conceptions of the future world order, such as U.S. involvement in Yugoslavia, Middle Eastern policies, sanctions against Iran and Iraq).

After realistically minded professionals led by Yevgeny Primakov took over responsibility for Russian foreign policy in 1996, they man- 
aged to fix a lot in the practical agenda. Through hard bargaining they negotiated the most pressing hard-security issues (NATO policies towards Russia and arms control). However, their elegant appeals to international law ("rules of the game" written with the participation of Soviet/Russian diplomats took into account Russia's basic interests and could not spell defeat) and the concept of multipolarity contributed to the divergence of Russian and Western views on general rules of international behavior. Russia and the U.S. increasingly argued over Iran and Iraq, but particularly over the civil war in Yugoslavia. After NATO launched its air campaign in Kosovo in the spring of 1999, relations between Russia and the West were the worst since the end of the Cold War. Remarkably, for both sides principles were at stake instead of vital material interests.

Putin's administration remained firm on hard-security interests, but, contrary to the late Yeltsin, did not escalate tough rhetoric on conceptual world order issues. Remarkably, during his last official foreign travel to China shortly before Yeltsin's resignation, Clinton said that Russia would pay a price for the conflict in Chechnya, Yeltsin publicly reminded him of Russia's global nuclear power status and its inherent role in setting global rules (Yeltsin stressed that Clinton would not be able to decide everything on his own, but rather would have to accept common Russian-Chinese views). Prime Minister Putin chose to downplay the issue in quite an elegant way; he remarked that that Clinton's critical comments on Russia's activities in Chechnya were rooted in "his [Clinton's] care for Russia not overburdening itself with additional problems," and these comments should not be used to provoke problems in Russian-U.S. relations, because "neither Clinton nor Yeltsin intended or meant that" (Putin, 2000: 11).

A year later the rhetoric of the winning Bush campaign, extremely critical of Clinton's international agenda, promised a revision of America's attitude to world order issues. But before it became clear what that promise had really meant, the 9/11 tragedy occurred and created an international situation where Russia and the U.S. once again viewed each other as being on the same side on something that seemed of critical importance. Although disagreements over ideational issues 
still surfaced, like in discussions concerning the invasion of Iraq, and later in a swordplay on democratization policy, and also in approaches towards responding to Iran's nuclear proliferation issue, Russia and the U.S. adopted an "agree to disagree" approach. To prevent erosion of the international community's unity on the fundamental Global Terror challenge, they decided to curb escalation of disagreements on conceptual issues. Essentially, it was a sort of compromise on the ideational agenda.

However, this compromise did not defuse the discrepancies on the practical agenda. The U.S. withdrew from the ABM Treaty, which Russia had traditionally viewed as the cornerstone of arms control and the most precise barometer of the state of Soviet Union/Russia-U.S. security cooperation. NATO expansion to Russia's borders was unsurprisingly taken by Russia as a serious security concern. Besides, NATO expansion stultified some of the recent amendments to the CFE Treaty. The U.S. interpreted the "agree to disagree" approach as "disagree, but do not impede," which Russia seemingly did not contest for a while. However, when U.S. policy in Eurasia began to assertively infringe on Russian interests in nearly all of the post-Soviet space, Moscow counteracted. Russia mirrored U.S. interpretation of the "agree to disagree" approach. These developments opened the way to further growth of mutual disagreements on many practical issues. They were pointed out by Putin in his Munich speech in 2007 and later climaxed in the Georgia conflict.

Obama's administration eagerly initiated a "reset" of Russian-U.S. relations, but it covered only the practical agenda. A new nuclear arms control treaty was signed. On many issues the two sides engaged in discussions aimed at curbing tensions and reconciling disagreements. Obama's reset policy was framed as a pragmatic dialogue with Russia, which was hardly able to accommodate ideational issues of the world order agenda. Although Obama's first administration put a lot of emphasis on talking to President Medvedev, it neglected his puppet initiative on a new security architecture in the Trans-Atlantic.

This contradicted Russia's expectations. Obama's campaign, heavily critical of the Bush administration's foreign policy, promised far less interventionism and unilateralism, which was 
seen in Moscow as a possibility for tackling disagreements of the ideational nature that could hardly be further hidden behind the counter-terror veneer. Obama talked on broad world order issues to Europe and wanted to talk to China (the Big Two issue), but not to Moscow. Left unattended and not overshadowed anymore by some fundamental agreement (like previously with War on Terror campaign), divergences escalated over the principles of international behavior. Soon they began to impede discussions of practical issues and contributed to disagreements over international crisis situations. Disagreements over Libya and Syria, as well as the Snowden episode, were extremely important cases of Russia's and the U.S.'s divergences on principles. Ultimately, the Ukrainian crisis of 2014 was fueled by both practical and ideational divergences.

To sum up, in the last twenty-five years the persisting dissonance on practical and ideational agendas prevented progress in RussianU.S. relations. While remaining interconnected, the two agendas are very distinctive, with each of them having its own impact on overall Russian-U.S. relations.

\section{CORRELATION BETWEEN PRACTICAL AND IDEATIONAL AGENDAS OF RUSSIAN-U.S. RELATIONS}

With the new spirit in Russian-U.S. relations there was an anticipation of some reconfiguration in bilateral relations. However, the political leadership on both sides lacked understanding of what exactly this should include. In February 1992 at Camp David one could see how assertive Yeltsin and Bush were in their declarations about the new "quality" and "spirit" of relations, but how little they could say on substance when asked by journalists at a joint press conference. The presidents left, as Bush phrased it, "substance to experts" to "discuss in much more detail” (Bush, 1992).

It seemed reasonable to assume that when the two sides had fewer disagreements they could do more together. This understanding fueled expectations of broader cooperation between Russia and the U.S. In reality, however, Russian-U.S. relations on both the practical and ideational agendas shrank dramatically. 
The U.S. took Russia's decreasing military and international standing as a natural post-Cold War development. At the same time, the emerging Russian elite saw the absence of confrontation with the West as an opportunity, if not a prerequisite, for internal development. Yeltsin sincerely (and quite in line with the public opinion in the late 1980s and early 1990s) regarded excessive foreign policy as a burden and wanted to get rid of it. He wrote that the Soviet Union's agencies "never gave a damn about the fate of Russia. They needed Russia solely as a supplier of raw materials, cannon fodder, and the main imperial 'magnet' which could attract virtually everything, even Cuba, and impose its own rules everywhere!" (Yeltsin, 1994).

At that time Russia believed that the excessive component of its foreign policy had been driven by ideological chimera. Paradoxically, the 1993 Foreign Policy Concept, which would soon be viewed in Russia as idealistically pro-Western, stressed pragmatism (not the pro-Western ideological momentum) as the underlying principle of the country's foreign policy. To put it simply, the West expected Russia's external interests to shrink (as a natural development rather than as a deliberate policy to weaken Russia), and Russia also wanted to reduce its international role (believing it to be pragmatic and not interpreting it as a weakness). This complementarity of views created a direct correlation between practical and ideational agendas, which worked in a positive way for Russian-U.S. relations while their scope was shrinking.

In the mid-1990s, Russia set the limits for the reductionist approach to its foreign and defense policies. The territorial integrity of Russia (the first Chechen conflict), the risk of a substantial rebalancing of conventional forces in Europe with the movement of NATO's military infrastructure closer to Russian borders, and the possible erosion of the strategic nuclear parity became such limits. Consequently, Russia's perception of pragmatism reversed from reducing the practical security and political agendas with the U.S. to extending it in order to reach some agreement with the U.S. on issues of Russia's vital concerns.

The U.S. took into account some of Russia's hard-security interests as they were professionally presented by Primakov's diplomacy, although 
to a far lesser degree than Russia had expected. At the same time, in their discussions of the practical agenda the two sides encountered more ideational issues. Russia's views on its territorial integrity, NATO expansion, and the balance of conventional forces in Europe were shaped primarily from the perspective of its vital national security interests, while the West's position was based on holistic principles which, it believed, should be placed above the self-interest of a nation and which Russia should merely accept. As Russia pushed for expansion of the practical agenda to defend its vital national interests, the correlation between practical and ideational agendas changed from positive to negative.

Since the second half of the 1990s, this negative correlation has been the reason why the dissonance between the two agendas repeatedly drove Russian-U.S. relations into confrontation, sometimes even despite the sides' good intentions. The scope of disagreements on practical issues increased in the 2000s, and so did Russia's will not to compromise its vital interests for the sake of holistic principles promoted by the West. This negative correlation manifested itself ever more vividly when Russia, in turn, victimized U.S. vital security interests for the sake of general principles, like in the Snowden affair. In this case Russia admitted that it was an extremely important issue for U.S. national security, but refused to assist it, making it clear to others (and not only to Russians, considering how many awards the Citizenfour documentary collected worldwide, including the Oscar) that there was something wrong with U.S. moral principles.

Importantly, attempts to achieve progress with one of the agendas of Russian-U.S. relations initially would ease disagreements on the other agenda. In other words, an early improvement of relations with one of the agendas is not blocked by disagreements on the other agenda. Each time that happens, hope appears that progress with one of the agendas can be sustained by delinking it from the other and overcoming the negative correlation. However, with time, disagreements on the under-scrutinized agenda grow to a level where they become more important (at least for one side) than progress made with the other agenda, then that progress is ultimately wiped out. Hence, there is only a temporarily improvement in relations. This happened 
in the late 1990s, when progress in the practical agenda was screwed up with the overwhelming clash on the Kosovo issue, a matter of basic principles of international behavior for each side. Another case was the failure of Obama's reset policy as an emphasis on the pragmatic agenda left ideational issues unattended.

The correlation between the practical and ideational agendas can be systematized using the notions of the mediation model, which interposes a mediator or an intervening variable into the relationship between dependent and independent variables. If U.S.-Russian relations and one of the agendas are assumed to be, respectively, dependent and independent variables, then the other agenda is an intervening variable. One of the agendas interferes in the direct causal relationship between dependent and independent variables. This occurs when the two agendas are in dissonance (when they are not in dissonance, then the casual relationship is direct).

Importantly, the influence of mediation is negative (because of the negative correlation discussed above) and changeable (it varies from partial to full). When an independent variable starts to change (for example, there is progress in discussing questions of one of the agendas) and influence the dependent variable (overall Russian-U.S. relations), the intervening variable (disagreements on the other agenda) exerts minimum influence.

At the initial stage the casual relationship between dependent and independent variables is nearly direct. However, at some point the influence of the independent variables on the dependent one noticeably diminishes (one may argue whether this is a result of gradual development or sudden occurrence) because the mediation power of an intervening variable grows substantially.

Arguably, it takes time for an intervening variable to gain power, but as it does, the direct relationship between the dependent and independent variable degrades quickly, and falls victim to the negative influence of the intervening variable. Sometimes Russia and the U.S. took steps to delink one agenda from the other by curbing the influence of an intervening variable. But this never worked well enough. Not being part of the direct relationship between the dependent and independent 
variables, an agenda that has been put aside reemerges as an intervening variable with the progressing power of negative influence.

\section{EXTENSION OF PRACTICAL AND IDEATIONAL AGENDAS OF RUSSIAN-U.S. RELATIONS}

Having exhausted the reductionist approach to its foreign and defense policies in the mid-1990s, Russia quickly re-interpreted the voluntary abandoning of the excessive foreign policy burden as its de-facto selfweakening. Moreover, many in Russia started to claim that the West was intentionally making use of Russia's weakness to keep it down. A day before becoming acting president Vladimir Putin claimed that perhaps for the first time in 200-300 years Russia was facing "a real risk of ending up in the second or even third echelon of states" (Putin, 1999).

Such marginalization was something Russia could not accept. For centuries Russian elites had shared a perception of their country as a great power with a strong messianic predestination. In fact, in the twentieth century this perception also became common with the general public (Interestingly, this great power gen and messianism was challenged by some of Russian great minds, including Leo Tolstoy and Alexander Solzhenitsyn, but unsuccessfully). The risk of marginalization motivated Russia for a revanche. A bit later it was conceptualized in the notion of "real sovereignty" (Kokoshin, 2006), understood as regained capability and will for an independent international standing.

High commodity prices in the 2000s opened up opportunities for Russia’s economic growth, which was further stimulated by domestic reforms. Russia's efforts to regain what it understood as real sovereignty coincided in time and space with growing U.S. interventionism. Expanding Russian and U.S. interests collided in the Middle East, Latin America, Eastern Europe and, particularly dramatically, in the former Soviet space. Growing military budgets funded new arms programs, which political experts on both sides took with suspicion and concern. As interests and capabilities increased, the scope of the practical agenda between Russia and the U.S. also widened. Today the vital national interests of Russia and the U.S. collide in many spots around the globe in hard security, economic, and political dimensions. 
Ideational disagreements between Russia and the U.S. have also extended. Whereas before Russia had felt comfortable with its reduced international role, now it raised its voice on world order issues, because it found Western approaches particularly unfair in some cases (like in the Kosovo conflict) and disastrous to Russian vital interests in others (NATO expansion). Not meeting enough understanding from the West (which expected Russia to be a good student to transit to the right side rather than raise its voice on global issues), Russia further shifted to modestly challenging the Western order.

Deprived of the opportunity for real input in the design of the new world order, Russia challenged the integrity of the Western order by highlighting double standards in the West's behavior. Making the point that the Western approach was not as good as it was declared, Russia, presumably, sent a message that it was still ready to accept the Western order (preferably with a greater Russian role), but with clearcut norms, including limitations for the West itself. As the growing U.S. interventionism indicated a movement exactly in the latter direction, Russia continued to highlight Western double standards, but with a different purpose, this time to legitimize its efforts to construct what official Russian diplomacy identifies as "the new architecture of global governance” (see, for example, Lavrov, 2017). Looking for partners to implement the idea, Russia found them outside of the Western world and established non-Western partner organizations (the SCO and BRICS). In fact, Russia engaged in an effort to build an international compact to challenge what it saw as escalating Western disorder. Defacto it opted for a foreign policy of doing something without the U.S. (and mostly without the West), but not against it.

Three events were particularly important for the further evolution of Russian foreign policy: the global financial crisis of 2008 that many in Russia interpreted as a sign of the relative decline of U.S. power; the WikiLeaks story; and the Snowden case, which revealed the misbehavior of the U.S. in world politics. It no longer spoke of U.S. "wellintended errors," but of the fact that the problem was the U.S. itself. In the Russian view, America was losing the power and moral credibility to be the master of the world. Russia was ready to contest not only the 
particular world order rules, but the very privilege of the U.S. for global leadership that the international community had taken for granted since the end of the Cold War.

In addition to the strong and persisting belief in Russia that the U.S. would never self-restrain itself in achieving what it regards as its vital national goals (a framework for the practical agenda), the Russian leadership also shaped a framework for the ideational agenda of relations with the U.S., namely that the U.S. maintains international spin to cover up the truth with a carefully engineered illusion. A year after the U.S. election, a senior aide to the Russian President, Vladislav Surkov, published an essay on the RT website, where he claimed that the West, and above all the U.S., was about to lose the ability to maintain its internal spin (Surkov 2017). The piece did not touch upon world politics directly, still all its logic implies that the international dimension of the American spin (hypocrisy) was also about to collapse.

Deprived of a chance to substantively contribute to the Western ideational consensus on the world order rules, Russia has been compelled to develop its own independent moral standing. By contrast, the West has found it necessary to respond to Russia's moral quest. Of course, the first reaction is to highlight an issue. A recent report by the U.S. Congress Helsinki Commission emphasizes how important the moral facet of foreign policy has become for Russia: "Today, it appears that the Kremlin is less interested in sanctions relief and is after something less tangible: moral equivalence" (Hope and McAndrews, 2018: 1). The recommendation of the report is to deny moral equivalence to Putin.

To conclude this stage of analysis it is worth returning to the beginning. Practical and, in particular, ideational agendas emerged from some very basic misunderstanding after the end of the Cold War. The West anticipated a radical rejection by Russia of its recent Soviet history and policy patterns, presumably considering that Russia would also reject its past great power history. Arguably, Russia was expected to go through the same transformation that other big European nations had undertaken under the American political and security leadership after 
WWII, the end result of which was the emergence of the new postmodern Europe (Kagan, 2003: 53-69).

However, Russia, just like most other nations withdrawing from failing universalistic Communist ideology, looked towards connections with the political West, but in broader terms, it anticipated a revival of its pre-Communist nature, which was more in line with what later was presented as thinking of revenge of history (Kaplan, 2012) than with a flat world vision (Friedman, 2005). Yeltsin wanted Russia to regain its historic, pre-Soviet, self; in the foreign policy realm it meant "returning to where we have always been, to the Entente, if you wish, to the alliance with Western powers" (Yeltsin, 1994). In other words, Russia intended to reduce excessive foreign policy to return to its traditional foreign agenda which was consistent with the West and its new world order. Meanwhile, the West expected a deep transformation of Russia away from its Soviet and pre-Soviet self in the direction of European post-modernism. Over time Russia denied the latter path (not least because the U.S. had not undertaken the same transformation) and extended material and non-material arsenals for its independent international standing.

\section{THE SYNTHESIS OF PREVIOUS STAGES OF ANALYSIS}

The inherent paradox of Russian-U.S. relations is that it was possible to improve them by delinking practical and ideational issues, but it was impossible to sustain those improvements because of that very delinking. Repeating dissonance between the practical and ideational agendas (which doomed to failure sincere efforts by Russia and the U.S. to put their relations on a positive trajectory and sustain it) persisted and ultimately brought them to a significant crisis.

During Obama's second and Putin's third terms in office something new and even worse happened. In 2012 the U.S. chose to narrow the venues for communication and the reset policy was terminated. For the first time since the end of the Cold War, Russia and the U.S. did not even try to fix at least one of the tracks; instead they used them as fields for competition rather than for reconciling disagreements. In these circumstances the two agendas finally resonated in a negative 
way: disagreements enhanced in both of them. The collapse of U.S.Russia relations on both agendas culminated in the crisis in Ukraine.

One may argue that the described model of coexistence of practical and ideational dimensions resembles the Cold War situation. Describing current Russian-U.S. relations as a new Cold War is not completely unfounded. Still, in a way it is substantively wrong. While the geopolitical component of the competition is very much the same, the fundamental clash of two existentially incompatible sociopolitical systems is not in place. In the second half of the twentieth century Russia and the U.S. shaped world politics in very broad terms. Now Russia and the U.S. are accommodating to the evolving international system, rather than shaping it.

Russia's material revanche was a concern for the West, but economic growth and integration into the world economy allowed investors to make money in Russia. Moreover, amid emerging powers Russia could be seen as one of the closest to the West, in particular to Europe, historically and culturally.

There was duality in Russia's position as well. While seeking equal cooperation with the West, the Russian authorities encouraged antiWestern, but particularly anti-American, sentiments in society and the elite. While the West's duality revealed fear and interest, Russia's duality was based on interest and almost complete rejection of everything associated with the West.

This prompted controversial tactics on both sides. The West's fear and interest substantiated practical programs for developing cooperation with Russia and containing it at the same time. Russia's interest and rejection of the West welcomed cooperation and greater independence in global affairs. Europe still stands for the same balance between, respectively, engagement vs. containment and cooperation vs. disengagement. It is not ready, let alone willing, to sacrifice one for the sake of the other.

The debate on values continues not only between Russia and the West, but also between Europe and the U.S. All together we stand in contrast to the rising Asian powers with their own values. Values play a key role in how societies are organized and governed, that is, in de- 
termining the internal situation in a country. A value-based domestic policy affects foreign policy and the methods and means a country uses to become more competitive in the modern world. But the recognition of this sequence (values-internal affairs-foreign policy) and the importance of values for domestic and foreign policies (essentially our positions are rooted in our values and for that reason are generally accepted as correct and justified) does not suggest existential competition between socio-political systems.

One more factor is important. During the Cold War, Russia and the U.S. knew less about each other than now due to political restrictions and objective technological limitations for the spread of information. Yet Russia took the U.S. for what it was and vice versa (exaggerations of each other's problems and caricature simplifications were made for propaganda purposes), although moral assessments of each other were basically negative. Now, with new technologies and less restrictions, Russia and the U.S. know (or at least have an opportunity to know) far more about each other, but, paradoxically, understand each other far less adequately.

The internal discourse in Russia and the U.S. can be framed in the following way. With the extension of material power on both sides, particularly rapid in Russia, professionals responsible for securing the country's vital interests, above all hard security, demand more resources. For that they need to raise the public's political awareness. Since it is impossible to present one as dangerous solely on the basis that he is strong, but only in combination that he is wrong (a bad guy) and we are right, the ideational agenda is built around the discourse of self-rightness and somebody's wrongness.

Current debates in Russia and the U.S. are at the stage when the material competition cannot be sustained by a narrow group of professionals without engaging broader political and social groups. The latter are not yet strong enough to mobilize material power for their purposes, but in the U.S. and Russia alike the elites have come very close to that. At the same time, Europe (at least Old Europe), unable to leave the comfortable mindset of the 2000s, tries to avoid this development. 
While the distinction between practical and ideational agendas helped identify dilemmas associated with their change, the pending question is how they can be reconciled. The negative correlation between the two agendas, which has been described above, proves that sustainable progress in Russia-U.S. relations cannot be achieved within one of them without reconciling the disagreements with the other one. Yet there is still one way to achieve that.

Hypothetically, Russia and the U.S. may stop escalating their war of ideas if their material interests do not cross. This would be possible if they divide their zones of influence and respect them. However, practically (even if we rename zones of influence as areas of responsibilities or find some other euphemisms for them) this is impossible with the U.S.'s position of "no more Munich." This means that sustainable material de-escalation of the conflict is hardly possible without eliminating non-material, ideational disagreements.

To continue with the good news, essentially Russian and U.S. conceptual positions are not aggressive. America's exceptionalism which presents it as "a shining city upon a hill" does not imply interventionism. It aims to demonstrate moral (rather than hard) power for everybody to follow its way. Russia's messianism suggests being concerned about everything in the world and relying on moral criteria, but not getting practically involved, except in very rare cases. Arguably, Russia and the U.S. do not have historical experience (except for a relatively short period before the Bolshevik revolution) in managing a great power relationship. Most direct Russian-U.S. relations existed in the atmosphere of a genuine Cold War, a clash of two existentially incompatible sociopolitical systems. The Cold War experience of not accepting each other (as each was perceived as willing to change the other), became part of the strategic culture on both sides. This attitude has doomed the two countries to wish for (and, if possible, to stimulate) each other's internal collapse or geopolitical retreat, or a combination of both. It will take some time before a meaningful number of strategists in both countries realize that this is either impossible or unadvisable (or both). This is unlikely to happen until the U.S. settles its internal crisis and until 
Russia proves that it is capable of supporting its material and moral ambitions over a long period of time. Importantly, the perception of Russian foreign policy in America is extremely personified (not without reason as Vladimir Putin's role in it is really enormous). Arguably, the West will be able to take Russia as it is only after Putin leaves, and if Russian foreign policy proves to be sustainable without Putin's personal factor.

The study of Russia-U.S. relations through an analysis of the interaction between their practical and ideational agendas helps describe the dynamics of these relations and their inherent dilemmas. The proposed approach is useful for understanding the unique conceptual landscape within which U.S.-Russia (and, more broadly, West-Russia) relations develop and which ultimately influences the process. For this purpose, it is used as a separate explanatory model. The approach also contributes to an analytical description of Russian-U.S. relations per se and the evolution of the views in each country with regard to the other country. The proposed approach can be integrated with other models, thereby improving their explanatory power.

\section{References}

Aven, P., and Kokh., A., 2013. Gaidar's revolution. The inside account of the economic transformation in Russia. London, New York: Tauris.

Baker, J.A., 1991. America and the post-coup Soviet Union. Public address. 12 December, C-Span [video online]. Available at: <https://www.c-span.org/ video/?23366-1/post-coup-soviet-union> [Accessed 12 November, 2018]

Bush, G.H.W., 1992. Welcome statement to President Yeltsin on U.S.-Russia Joint Statement. Camp David, Md., 1 February, C-Span [video online]. Available at: <https://www.c-span.org/video/?40850-1/us-russia-joint-statement> [Accessed 14 November 2018].

Declaration, 1992. Joint Declaration on U.S.-Russia Relations by President Bush and President Boris N. Yeltsin. Camp David, Md., 2 February. 
Fenenko, A., 2017. Alternatives to "liberal order". RIAC website, 13 January. Available at: <http://russiancouncil.ru/blogs/alexei-fenenko/32562/> [Accessed 14 December 2018].

Friedman, T., 2005. The World is Flat: A Brief History of the Twenty-first Century. New York: Farrar, Straus and Giroux.

Goldgeier, J.M., and McFaul, M., 2003. Power and purpose. U.S. policy toward Russia after the Cold War. Washington D.C.: Brookings Institution Press, 2003.

Graham, T., and Rojansky, M., 2016. America's Russia policy has failed. Foreign Policy, 13 October [online]. Available at: <https://foreignpolicy. com/2016/10/13/americas-russia-policy-has-failed-clinton-trump-putinukraine-syria-how-to-fix/> [Accessed 14 November 2018].

Hope, S., and McAndrews S., 2018. What's Next in Putin's Crosshairs? Helsinki Commission Report, 18 October.

Kagan, R., 2003. Of paradise and powers: America and Europe in the new world order. New York: Vintage.

Kaplan, R., 2012. The revenge of geography: What the map tells us about coming conflicts and the battle against fate. New York: Random House.

Karaganov, S., 2018. How to win a Cold War. Russia in Global Affairs [online], 18 July. Available at: <https://eng.globalaffairs.ru/pubcol/How-to-Win-a-ColdWar--19732> [Accessed 14 December 2018].

Kokoshin, A., 2006. Realnyī suverenitet v sovremennoī miropoliticheskoì sisteme [Real sovereignty in modern world political system]. Moscow: Evropa.

Kortunov, A., 2016. The inevitable, weird world. RIAC website, 20 July [online]. Available at: <http://old.russiancouncil.ru/en/inner/?id_4=7930\#top-content > [Accessed 14 December 2018].

Lavrov, S., 2017. Address at the Moscow Security Conference, 26 April [online] Available at: <https://interaffairs.ru/news/show/17438> [Accessed 14 December 2018].

McFaul, M., Sestanovich, S., and Mearsheimer, J.J., 2014. Faulty Powers. Who Started the Ukraine Crisis? Foreign Affairs, 93(6).

Mearsheimer, J.J., 2001. The Tragedy of Great Power Politics. New York: W.W. Norton \& Company.

Mearsheimer, J.J., 2014. Why the Ukraine Crisis Is the West's Fault. The Liberal Delusions That Provoked Putin. Foreign Affairs, 93(5). 
Miller, A., and Lukyanov, F., 2016. Detachment instead of confrontation: PostEuropean Russia in search of self-sufficiency. Report delivered at The Bruno Kreisky Forum for International Dialogue, October.

Nikonov, V., 2015. Russia in the Contemporary World. Strategies of Russia, Vol. 7. Putin, V., 1999. Rossiia na rubezhe tysiacheletiī [Russia on the Verge of Millennia]. Nezavisimaya Gazeta, 30 December [online]. Available at: <http:// www.ng.ru/politics/1999-12-30/4_millenium.html> [Accessed 15 November 2018].

Putin., V., 2000. Press-clippings. Yadernyī Kontrol' [Nuclear Control] Journal), Vol. 2.

Safranchuk, I., 2008. Traveling in Different Boats. Russia in Global Affairs, 6(4).

Shevtsova, L., 2010. Lonely Power. Carnegie Endowment for Int'l Peace, 2010.

Starr, S.F., and Cornell, S.E., eds., 2014. Introduction in Putin's Grand Strategy: The Eurasian Union and Its Discontents. Johns Hopkins University-SAIS.

Surkov, V. 2017. Krizis Lytsimeriya. "I hear America singing” [Hypocrisy crisis. "I hear America singing"]. RT.com, 7 November [online]. English translation by Ollie Richardson and Angelina Siard. Available at: $<\mathrm{http} / /$ www.stalkerzone. org/vladislav-surkov-crisis-hypocrisy-hear-america-singing/> [Accessed 15 November 2018]

Trenin, D., 2009. "Moscow the muscular": The loneliness of an aspiring power center. Carnegie Moscow Center Briefing, 11(1) [online]. Available at: <https:// carnegie.ru/2009/01/01/moscow-muscular-loneliness-of-aspiring-powercenter-pub-23567> [Accessed 14 December 2018].

Waltz, K.N., 1979. Theory of international politics. New York: Waveland Press. Yeltsin, B., 1994. Zapiski prezidenta [Notes of the President]. Moscow: ROSSPEN. 